\title{
Isolation and characterization of the mutant form of N-terminal catalytical module of Bos taurus tyrosyl-tRNA synthetase with the replacement of Trp 40 and Trp 283 by alanine
} \author{
A. I. Kornelyuk ${ }^{1}$ \\ ${ }^{1}$ Institute of Molecular Biology and Genetics, NAS of Ukraine \\ 150, Akademika Zabolotnoho Str., Kyiv, Ukraine, 03143 \\ 2 Institute of High Technologies, Taras Shevchenko National University of Kyiv \\ 2, korp.5, Pr. Akademika Hlushkova, Kyiv, Ukraine, 03022 \\ v.n.zayets@gmail.com
}

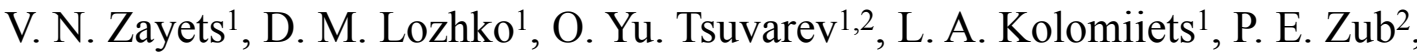

\begin{abstract}
Aim. To obtain the mutant one-tryptophan form of the N-terminal catalytical module of Bos taurus tyrosyl-tRNA synthetase (mini TyrRS) for the monitoring of the local conformational changes by fluorescence spectroscopy. Methods. Bacterial expression, metal-chelating chromatography, gel electrophoresis, fluorescence spectroscopy, computational modeling. Results. The replacement of two tryptophan codons with alanine codons in cDNA encoding mini $B t$ TyrRS has been performed. These mutations do not affect the synthesis and solubility of the mini $B t$ TyrRS in $E$. coli BL21 (DE3) pLysE strain. The amount of a soluble form of the mutant mini $B t$ TyrRS in the cytoplasm of bacterial cells at the incubation of bacterial culture at $25{ }^{\circ} \mathrm{C}$ was about $47 \%$ of the total amount of recombinant protein. Computational modeling and fluorescence study of the single-tryptophan form of mini BtTyrRS revealed that Trp 87 residue was localized at the dimerization region of the enzyme. The characteristics of tryptophan fluorescence of the mutant mini BtTyrRS indicated that Trp 87 is localized in the immobilized microenvironment of the dimer interface. Conclusions. The optimal conditions of bacterial expression of the mutant Trp 87-containing form of mini BtTyrRS in the bacterial culture of E. coli strain BL21 (DE3) pLysE have been established. The Trp 87-containing form of mini $B t$ TyrRS is suitable for monitoring the local conformational changes at the enzyme dimer interface.
\end{abstract}

Ke y w o r d s: tyrosyl-tRNA synthetase, mini TyrRS, bacterial expression, fluorescence spectroscopy, computational modeling

(C) 2020 V. N. Zayets et al.; Published by the Institute of Molecular Biology and Genetics, NAS of Ukraine on behalf of Biopolymers and Cell. This is an Open Access article distributed under the terms of the Creative Commons Attribution License (http://creativecommons.org/licenses/by/4.0/), which permits unrestricted reuse, distribution, and reproduction in any medium, provided the original work is properly cited 


\section{Introduction}

Aminoacyl-tRNA synthetases (ARSases) [EC 6.1.1] are the key enzymes of protein biosynthesis. At the preribosomal stage of translation, ARSases catalyze the activation and covalent attachment of the amino acids to the homologous transfer RNAs, thus carrying out the initial stage of the realization of genetic information into the protein structure $[1,2]$.

Mammalian tyrosyl-tRNA synthetase (TyrRS, EC 6.1.1.1) is one of the most studied eukaryotic ARSases. Under physiological conditions, Bos taurus tyrosyl-tRNA synthetase is an $\alpha_{2}$ homodimer with a molecular weight of $2 \times 59.2 \mathrm{kDa}$. Each monomer consists of two structural parts: the N-terminal catalytic form (mini BtTyrRS, $39 \mathrm{kDa}$ ) and the C-terminal EMAP II-like module (20 kDa) [2]. During the isolation of TyrRS from bovine liver, it was shown that along with the full-length main form, the functional proteolytically modified form of tyrosyl-tRNA synthetase with a molecular weight of $39 \mathrm{kDa}$ was released, which retains its enzymatic activity in vitro [3, 4].

In addition to the basic tRNA aminoacylation function the mammalian tyrosyl-tRNA synthetases perform also the non-canonical functions: after enzymatic cleavage of tyrosyltRNA synthetase by elastase into mini $B t$ TyrRS and C-module, the latter exhibit cytokine properties, thus linking the protein biosynthesis with cell signaling systems $[5-7,8]$.

The tests for cytokine activity of the $\mathrm{N}$-terminal catalytic domain of $B t$ TyrRS revealed that mini TyrRS is a chemotaxic factor for neutrophils, activates the migration of endothelial cells and polymorphonuclear leuko- cytes and stimulates angiogenesis in a concentration-dependent manner. The cytokine activity of mini TyrRS has been shown to be mediated by conservative ELR motif in the Rossman fold of the catalytic domain $[7,8]$.

Since the N-terminal catalytic module of the Bos taurus tyrosyl-tRNA synthetase is an interleukin-like cytokine and exhibits proangiogenic properties, it is a promising object for investigation. In the structure of the BtTyrRS catalytic module there are 3 tryptophan residues, which are respectively located in the active center of the enzyme (W40), in the region of dimerization of mini $B t$ TyrRS monomers (W87) and in the binding site of the tRNA anticodon triplet (W283). Such location of tryptophan residues in the functionally important regions of the protein's amino acid sequence makes it very promising to study the properties by fluorescence spectroscopy, especially if there is only one residue in one of three positions in the enzyme structure. Previously, we have cloned the cDNA of the tyrosyl-tRNA synthetase catalytic module in the expression plasmid pET32a and investigated its expression [9]. Subsequently, Trp40 and $\operatorname{Trp} 283$ codons were replaced with alanine codons by site-directed mutagenesis in cloned cDNA and only one tryptophan codon was left at the site of dimerization of mini BtTyrRS monomers [10].

The purpose of this work was to determine the optimal expression conditions of mutant mini BtTyrRS and to isolate the recombinant protein for further study of its properties, especially the local conformational changes at the enzyme dimer interface. 


\section{Materials and Methods}

In order to obtain the mutant form of Bos taurus mini TyrRS we used the bacterial expression system of $E$. coli cells [11-13]. The synthesis of recombinant protein was carried out in the E. coli strain BL21 (DE3) pLysE (Stratagene, USA) transformed with pET30a39KYRSW87 plasmid.

The pET30a-39KYRSW87 expression construction was created on the basis of the $\mathrm{pET}$ $30 \mathrm{a}(+)$ vector ("Novagen", USA) and contained a cloned cDNA with the tryptophan-40 and tryptophan-283 codons replaced by alanine codon. A plasmid DNA was isolated using the Gene JET Plasmid Miniprep Kit from "Thermo Scientific". The concentration of plasmid DNA was determined on NanoDrop 2000 spectrophotometer ("Thermo Scientific").

In order to obtain the recombinant plasmid construct pET30a-39KYRSW87, transform it into E.coli cells and express the mutant cDNA of the catalytic module B.taurus tyrosyl-tRNA synthetase, the genetically engineered $E$. coli DH5 $\alpha$ and BL21 (DE3) pLysE strains were used. Competent E. coli cells were obtained according to the Inoue method [14]. All procedures for transformation of plasmid pET30a39KYRSW87 into competent $E$. coli cells and analysis of plasmid by $0.7-1 \%$ agarose gel electrophoresis were performed according to [15].

The cultivation of E. coli BL21 (DE3) pLysE cell culture and the induction of expression of recombinant mini BtTyrRS in bacterial culture were performed in Luria-Bertani medium (LB) with $30 \mu \mathrm{g} / \mathrm{ml}$ kanamycin. Transformed with recombinant plasmid pET30a-39KYRSW87, the competent E. coli BL21 (DE3) pLysE cells were grown on a shaker (BioSun Shaker Incubator ES-20) at $37^{\circ} \mathrm{C}$ to an optical density of $\mathrm{A}_{600}==0.6-0.8$ and the target protein synthesis was induced by adding $1 \mathrm{M}$ isopropyl- $\beta$-D-thiogalactopyranoside (IPTG) up to $1 \mathrm{mM}$ concentration followed by incubation at $37{ }^{\circ} \mathrm{C}$ for 4 hours and at $30^{\circ} \mathrm{C}$ and $25^{\circ} \mathrm{C}$ for 12 hours. The collected biomass from $100 \mathrm{ml}$ of culture was resuspended in $12 \mathrm{ml}$ of cell lysis buffer (50 mM sodium phosphate buffer, pH8.0, $500 \mathrm{mM} \mathrm{NaCl}, 10 \mathrm{mM}$ imidazole, $5 \mathrm{mM}$ $\beta$-mercaptoethanol). Cells lysis was performed using an ultrasonic disintegrator (6 cycles of $20 \mathrm{~s}, 20 \mathrm{~s}$ intervals). The lysate was clarified by centrifugation at $13000 \mathrm{rpm}$ for $30 \mathrm{~min}$ at $4{ }^{\circ} \mathrm{C}$.

The supernatant was applied to a Ni-NTA agarose column previously washed with $10 \mathrm{ml}$ of washing buffer $(50 \mathrm{mM}$ sodium phosphate buffer, $\mathrm{pH} 8.0,500 \mathrm{mM} \mathrm{NaCl}, 20 \mathrm{mM}$ imidazole, $5 \mathrm{mM} \beta$-mercaptoethanol) and with lysis buffer. Recombinant protein was eluted with $5 \mathrm{ml}$ of elution buffer $(50 \mathrm{mM}$ sodium phosphate buffer, $\mathrm{pH}$ 8.0, $150 \mathrm{mM} \mathrm{NaCl}, 200 \mathrm{mM}$ imidazole, $5 \mathrm{mM} \beta$-mercaptoethanol). All protein containing fractions were combined and dialyzed against $500 \mathrm{ml}$ of dialysis buffer (500 mM sodium phosphate buffer $\mathrm{pH} 8.0$, $150 \mathrm{mM} \mathrm{NaCl}$ ) for 20 hours at $+4{ }^{\circ} \mathrm{C}$. The concentration of purified mini BtTyrRS mutant protein was determined spectrophotometrically on BioMate- 5 spectrophotometer using a molar extinction coefficient of $27850 \mathrm{M}^{-1} \mathrm{~cm}^{-1}$ at a wavelength of $280 \mathrm{~nm}$. The optical absorption coefficient of mini BtTyrRS was determined by amino acid analysis of protein using ProtParam server (http://expasy.ch/cgibin/protparam). According to the ProtParam server, the molecular weight of the obtained recombinant 
mutant mini BtTyrRS is $47364.36 \mathrm{Da}$ and isoelectric point $\mathrm{pI}=6.42$.

Expression of the recombinant proteins was analyzed by SDS-PAGE [16].

Gels were stained with Coomassie blue R250 dye. The estimation of the amount of recombinant protein in the precipitate and in the supernatant fraction on the electrophoregram was performed densitometrically on a ChemiDocTM XRS + system instrument ("BioRad", USA).

The amino acid sequence of Bos taurus TyrRSs was used from the NCBI Gene database (https://www.ncbi.nlm.nih.gov/protein/) with identification numbers DAA32266.1. The three-dimensional crystal structures were obtained from RCSB PDB archive. Threedimensional coordinates of the protein structural templates were obtained from Protein Data Bank (PDB) (http://www.pdb.org/pdb). Visualization and analysis of protein structure were performed using UCSF Chimera software [17]. The spatial structures of the BtTyrRS dimer and double mutant BtTyrRSW87 were modelled from the crystal structures of $H s$ TyrRS (PDB codes $1 \mathrm{~N} 3 \mathrm{~L}: \mathrm{A}$ ) as templates using SWISS-MODEL web-server [18]. Highresolution protein structure refinement was done by ModRefiner [19]. The final model of $B t$ TyrRS structure was validated by the MolProbity server [20].

All fluorescence spectra were recorded at $25{ }^{\circ} \mathrm{C}$ on a Hitachi Model 850 fluorescence spectrophotometer equipped with thermostated cell holder (Hitachi Ltd., Japan). Fluorescence measurements were performed in a quartz cell with an optical path length of $0.5 \mathrm{~cm}$. The temperature in the quartz cuvette was determined within $+0.2^{\circ} \mathrm{C}$. Both excita- tion and emission slits of $5 \mathrm{~nm}$ were used in all fluorescence measurements. The excitation light wavelength was $280 \mathrm{~nm}$ or $295 \mathrm{~nm}$, the wavelength interval for the fluorescence spectra was 300-400 nm and the fluorescence registration was performed at the $90^{\circ}$ angle to the beam direction.

\section{Results and Discussion}

Previously, we have cloned and sequenced the complete nucleotide sequence of cDNA of the Bos taurus tyrosyl-tRNA synthetase gene [2]. Based on cDNA, an expressive plasmid construct of pET-30a (+)-39KYRS was created with a cloned sequence of the synthetase $\mathrm{N}$-terminal catalytic module. Expressed in strain E. coli BL21 (DE3) recombinant mini $B t$ TyrRS retained the aminoacylating ability inherent in the native aminoacyl-tRNA synthetase.

Based on site-directed mutagenesis, the recombinant plasmid pET-30a (+)-39KYRS was used to create the substitutions of tryptophan residues at positions 40 and 283 by alanine in the cDNA of the synthetase catalytic module [10]. The resulting plasmid pET-30a39KYRSW87 having only one tryptophan codon in the cloned cDNA was used in this work to obtain one-tryptophan protein for further fluorescence studies of conformational features and intramolecular interactions in protein structure $[21,22]$. The amino acid alanine was selected for site-directed mutagenesis due to its small hydrophobic radical, which does not affect a secondary protein structure formed by the adjacent amino acid residues in the polypeptide chain.

A considerable amount of recombinant protein is required to investigate the properties of 
the enzyme by experimental methods. Since the final yield of the target recombinant protein in bacterial systems strongly depends on the culture conditions, the experimentally determined optimal parameters for the expression of mini BtTyrRS in E. coli are required [9,10].

The native mini $B t$ TyrRS cloned in plasmid pET-30a-39KYRS was used to determine the conditions of its optimal expression in the $E$. coli system [9]. It was shown that the highest level of synthesis of recombinant mini $B t$ TyrRS in E.coli culture was achieved by adding to the culture medium of IPTG at a concentration of $1 \mathrm{mM}$ in the logarithmic phase of growth of the culture when it reaches an optical density OD600 $=0.7-0.9$ for the induction of protein synthesis and incubation of the culture for 4 hours at $37^{\circ} \mathrm{C}$. It was found that the composition of the culture medium had no significant effect on the expression of the enzyme.

We used these experimentally established optimal expression conditions to express and obtain a mutant single-tryptophan form of mini $B t$ TyrRS in transformed plasmid pET30a39KYRSW87 E. coli cell culture of strain BL21 (DE3) pLysE.

It is known that the sequence of the cloned genes in the expression vectors of the $\mathrm{pET}$ series plays a significant role in both the synthesis of recombinant proteins and obtaining soluble fraction of newly synthesized proteins [13]. Therefore, the replacement of two tryptophan residues with alanine in the mini $B t$ TyrRS structure in our case could be critical and lead to a decrease in enzyme synthesis or its transition into insoluble inclusion bodies. In this regard, we simultaneously expressed in E. coli mutant and native mini BtTyrRS forms of plasmids pET-30a $(+)-39$ KYRS and
pET30a-39KYRSW87. Our preliminary electrophoretic data showed that the mutations did not affect the expression of the mutant protein: the number of native and mutant forms of the tyrosyl-tRNA synthetase catalytic module synthesized in bacterial cultures was almost the same. However, our analysis of cell precipitate after clarification of bacterial lysates in the process of protein isolation showed that the majority of both native and mutant forms of the enzyme are in the cytoplasm in insoluble fraction of the inclusion bodies (results not shown).

The temperature of incubation is one of the major factors affecting the transition of recombinant proteins during expression in E. coli to the aggregated state, especially in vectors of the pET series with the extremely strong RNA polymerase promoter of phage T7 [13, 23, 24]. Therefore, it was decided to analyze the expression of the target protein in E. coli culture of strain BL21 (DE3) pLysE after IPTG induction at a lower incubation temperature of $30^{\circ} \mathrm{C}$ and $25^{\circ} \mathrm{C}$. The results of the analysis are shown in Fig. 1 (A, B). The experimental data showed that with decreasing temperature of the bacterial culture growth, the amount of synthesized recombinant protein in the soluble fraction increased in proportion to the temperature decrease. The highest amount of recombinant mini BtTyrRS in soluble cytoplasmic cell fraction was obtained at the incubation temperature of $25^{\circ} \mathrm{C}$. At this temperature, the soluble fraction was about $47 \%$ of the total amount of recombinant protein synthesized, whereas at $37^{\circ} \mathrm{C}$ it was only $13 \%$.

The established conditions for optimal expression of the catalytic N-terminal module of the Bos taurus tyrosyl-tRNA synthetase in 
$\boldsymbol{A}$

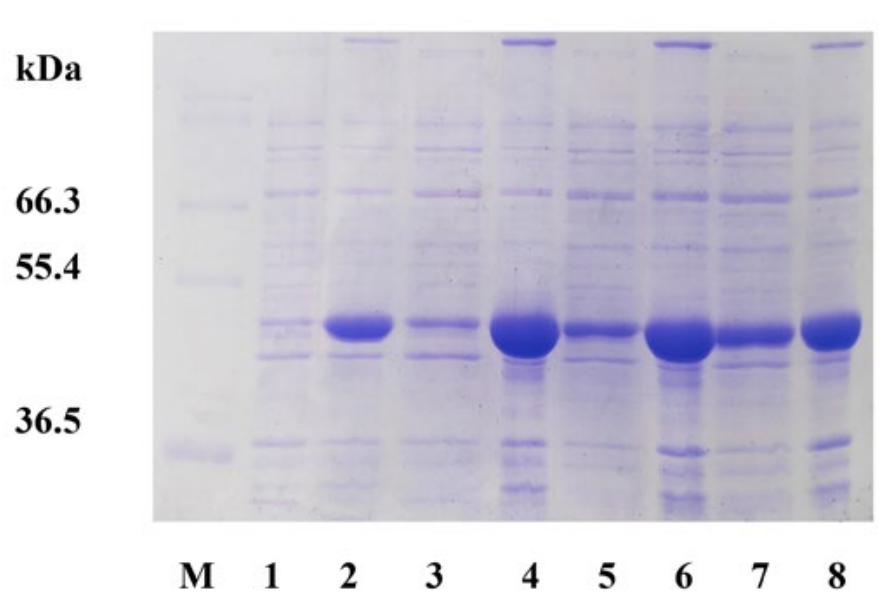

B

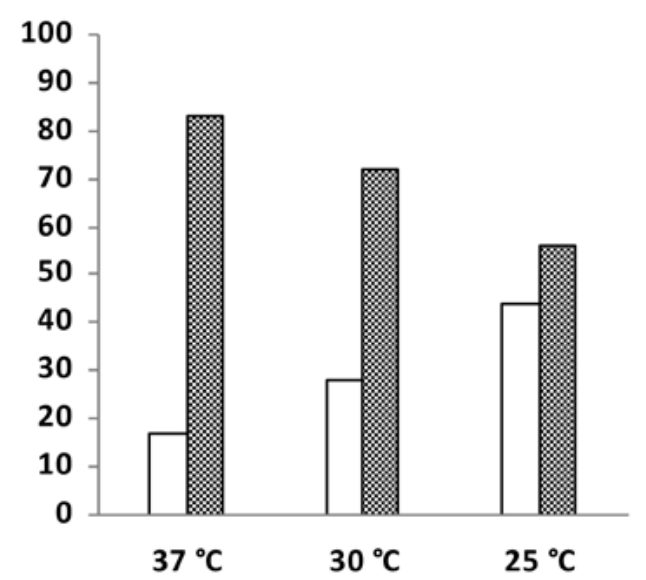

Fig.1. Electrophoretic and densitometric analysis of the mutant form of mini BtTyrRS expression in E. coli BL21 (DE3) pLysE strain transformed with plasmid pET30a-39KYRSW87 after culture growth at $37{ }^{\circ} \mathrm{C}, 30{ }^{\circ} \mathrm{C}$ and $25^{\circ} \mathrm{C}$.

A) Electrophoretic analysis of expression of a mutant form of mini BtTyrRS in E. coli strain BL21 (DE3) pLysE at a culture incubation temperature of $37^{\circ} \mathrm{C}, 30^{\circ} \mathrm{C}$ and $25^{\circ} \mathrm{C}$.

M - Mixture of marker proteins ("' Invitrogen ', Mark 12 Unstained Standart).

1 - Cell lysate of bacterial culture of E. coli strain BL21 (DE3) pLysE before IPTG induction.

2 - Cell lysate of bacterial culture of E. coli strain BL21 (DE3) pLysE after induction of IPTG.

3, 5, 7 - Cytoplasmic soluble fractions of cell lysates of bacterial cultures E. coli strain BL21 (DE3) pLysE after 4 hours of culture growth at $37^{\circ} \mathrm{C} \mathrm{(3),} 8$ hours of culture growth at $30^{\circ} \mathrm{C}(5)$ and 8 hours of culture growth at $25^{\circ} \mathrm{C}(7)$. 4, 6, 8 - Insoluble fractions of cell lysates of bacterial cultures of $E$. coli strain BL21 (DE3) pLysE after 4 hours of culture growth at $37{ }^{\circ} \mathrm{C}, 8$ hours of culture growth at $30^{\circ} \mathrm{C}$ and 8 hours of culture growth at $25^{\circ} \mathrm{C}$.

B) Percentage of synthesized mutant mini $B t$ TyrRS in soluble (unshaded box) and insoluble (shaded box) fractions of E. coli BL21 (DE3) pLysE cells after incubation at $37^{\circ} \mathrm{C}, 30^{\circ} \mathrm{C}$ and $25^{\circ} \mathrm{C}$.

E. coli in LB medium were taken into account when obtaining a preparative amount of recombinant mutant mini BtTyrRS in E. coli strain BL21 (DE3) pLysE using metal chelating chromatography. After lysis of bacterial cells by sonication and chromatographic purification of lysate on Ni-NTA agarose from $100 \mathrm{ml}$ of the bacterial culture incubated at $25^{\circ} \mathrm{C}$ for 8 hours we could get up to $3 \mathrm{mg}$ of homogeneous recombinant protein of the mutant mini BtTyrRS, with the purity according to electrophoresis about $95 \%$ (Fig. 2). Up to $30 \mathrm{mg}$ of purified recombinant enzyme can be obtained from 1 liter of bacterial culture under certain conditions of expression. Taking into account the aggregated protein in the inclusion bodies, the total yield of the synthesized recombinant mini BtTyrRS in transformed plasmid pET30a-39KYRSW87 strain E. coli BL21 (DE3) pLysE was about $75 \mathrm{mg}$ from the 1L LB medium.

According to the ProtParam program analysis, both native and mutant mini BtTyrRS proteins are stable structures. Their instability indexes are almost identical, 36.2 and 37.15, respectively, indicating that there is no appre- 


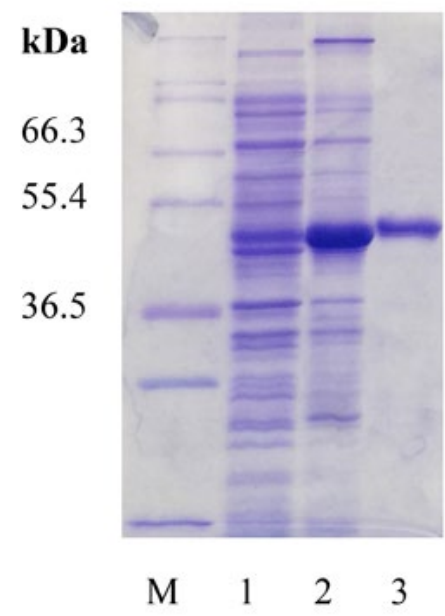

Fig. 2. Electrophoretic analysis of the expression of the mutant form of Bos taurus tyrosyl-tRNA synthetase in $E$. coli BL21 (DE3) pLysE strain and electrophoretic control of the purity of the mutant protein after chromatographic purification on Ni-NTA agarose $(12 \%$ acrylamide gel).

M - Mixture of marker protein (" Invitrogen ', Mark 12 Unstained Standart).

1 - Cell lysate of bacterial culture of $E$. coli strain BL21 (DE3) pLysE, transformed with plasmid pET30a39KYRSW87 before IPTG induction of mutant mini BtTyrRS synthesis.

2 - Cell lysate of bacterial culture of $E$. coli strain BL21 (DE3) pLysE, transformed with plasmid pET30a39KYRSW40 after IPTG induction of mutant form mini $B t$ TyrRS synthesis.

3 - Mutant mini BtTyrRS after chromatographic purification on Ni-NTA agarose.

ciable effect of substitutions of two tryptophan residues by alanine on the stability of the miniTyrRS mutant protein.

To evaluate the structure of the mutant form of mini BtTyrRS, we applied the computational modelling method for estimation of the homodimers of native and mutant catalytic modules of Bos taurus TyrRS, microenvironment analysis of tryptophan- 87 residue in the dimerization region of protein and fluorescence studies of the mutant mini TyrRS form.

The computational models of the spatial structure of the catalytic modules were constructed on the basis of the X-ray crystallographic data of the N-terminal catalytic module of human tyrosyl-tRNA synthetase [25] and the computational model of the structure of the full-length Bos taurus tyrosyl-tRNA synthetase [26]. The models of spatial structure of native and mutant mini BtTyrRS homodimers with highlighted tryptophan residues in positions 40, 87, 283 in native and in position 87 in mutant forms of the enzyme are shown in Figures 3 and 4, respectively.

Tryptophan 87 in each subunit of mini $B t$ TyrRS is localized at the contact area of protein monomers of the functional mini $B t$ TyrRS. The replacements of two tryptophan residues in mini $B t$ TyrRS by alanine did not resulted in any visible changes of its 3D structure.

Similar data were obtained from the comparison of the spatial structural organization of the contact regions of protein monomers in the environment of the Trp87 residue in native and mutant forms of mini BtTyrRS (Fig. 5). They also did not show any obvious changes after mutagenesis in the structure of the recombinant enzyme.

With the help of UCSF Chimera software the environments of Trp87 residue in the sphere of radius $5 \AA$ in both the native and mutant forms of $B t$ TyrRS were visualized and analyzed (Table 1). The analysis showed that there are 11 residues in the given region around $\operatorname{Trp} 87$ : 6 hydrophobic (Tyr79, Ala85, Leu89, Leu90, Thr121, Leu131), two negatively charged residues (Glu88, Glu91), two positively charged 


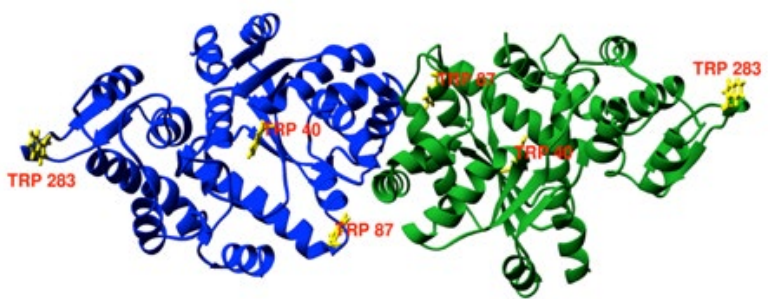

Fig. 3. Location of Trp residues in the $3 D$ structure of mini $B t$ TyrRS. Different protein monomers are highlighted in blue and green

residues (Lys127, Arg135) and neutral Pro86. Table 1 represents the distances from the $\mathrm{C}_{\mathrm{a}}$ atom of Trp87 to the $\mathrm{C}_{\mathrm{a}}$ atom of the corresponding residue in the native and mutant forms of $B t$ TyrRS. It can be seen that the Trp87 microenvironment is similar in both forms. We observed only minor changes in the solvent accessibility of $\operatorname{Trp} 87$.

The fluorescence spectrum of the mutant form of the catalytic modulus of Bos taurus tyrosyl-tRNA synthetase at the excitation wavelengths of $280 \mathrm{~nm}$ and $295 \mathrm{~nm}$ are shown

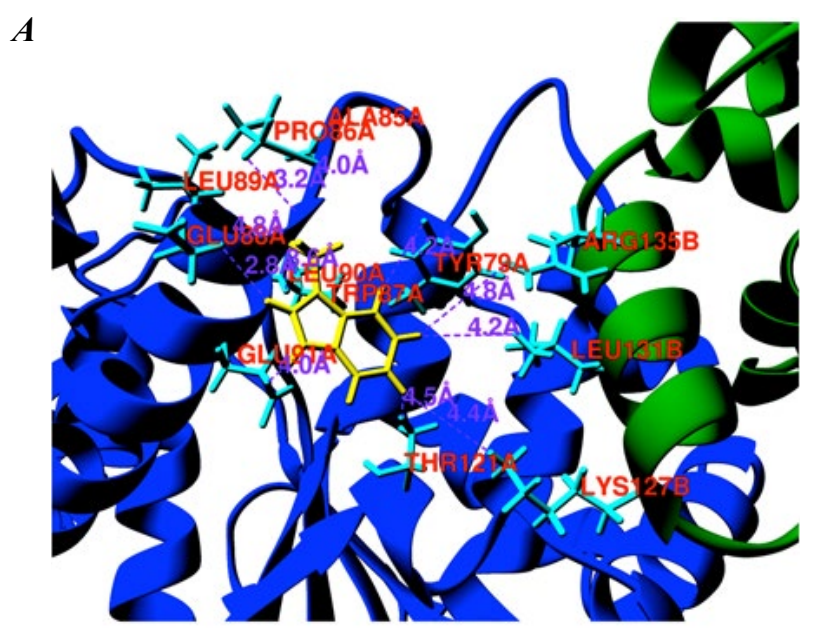

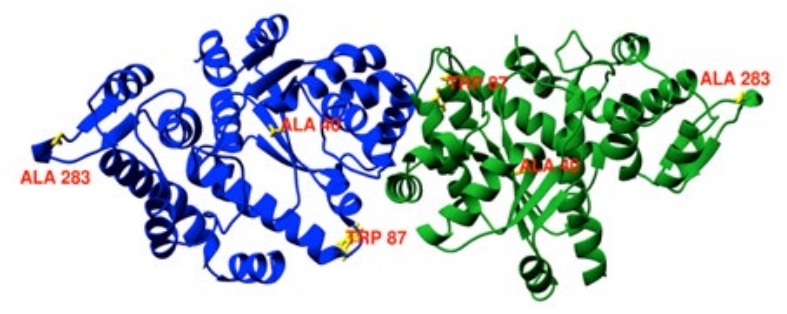

Fig. 4. The spatial structure of the mutant mini $B t$ TyrRS with the replacement of Trp40 and Trp283 by alanine. Different protein monomers are highlighted in blue and green

in Fig. 6. The determined fluorescence characteristics of the mutant protein, in particular, the position of the fluorescence maximum, $\lambda_{\mathrm{m}}$, and the half-width of the fluorescence spectra, $\Delta \lambda$, are $338 \mathrm{~nm}$ and $60 \mathrm{~nm}$, respectively.

According to the three spectral classes model of tryptophan residues in protein structure, the tryptophan residue at position 87 refers to the spectral class II, which is characterized by the emission of indole fluorophore immobilized in the concavity on the surface of the protein, and does not contact with free but only

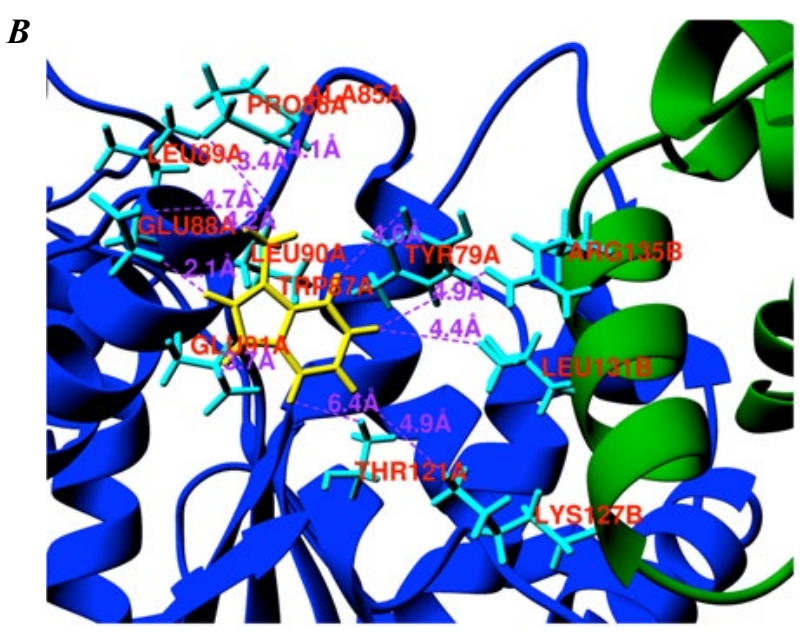

Fig.5. Microenvironments of Trp 87 residue of mini BtTyrRS homodimers at the interface area in the native (A) and mutant (B) enzyme forms. The regions of different monomers are highlighted in blue and green 
The mutant form of N-terminal catalytical module of B. taurus TyrRS with the replacement of Trp 40 and Trp 283 by alanine

Table 1. Amino acid environment and solvent accessibility of Trp87 in native and mutant forms of mini BtTyrRS

\begin{tabular}{l|l|l|l|l|l}
\hline $\begin{array}{c}\text { Amino acid environment of } \\
\text { Trp87 in } B t \text { TyrRS (native form) }\end{array}$ & $\begin{array}{c}\text { Distance } \\
\text { between } \\
\text { atoms, } \AA\end{array}$ & $\begin{array}{c}\text { Accessibility } \\
\text { to solvent } \\
\text { (Surface area, \%) }\end{array}$ & $\begin{array}{c}\text { Amino acid environment of } \\
\text { Trp87 in } B t \text { TyrRS (mutant form) }\end{array}$ & $\begin{array}{c}\text { Distance } \\
\text { between } \\
\text { atoms, } \AA\end{array}$ & $\begin{array}{c}\text { Accessibility } \\
\text { to solvent } \\
\text { (Surface area, \%) }\end{array}$ \\
\hline Tyr79A & 4.2 & 15.6 & Tyr79A & 4.6 & 18.6 \\
\hline Ala85A & 4.0 & 31.7 & Ala85A & 4.1 & 26.0 \\
\hline Pro86A & 3.2 & 72.8 & Pro86A & 3.4 & 75.4 \\
\hline Glu88A & 2.8 & 85.5 & Glu88A & 2.1 & 82.8 \\
\hline Leu89A & 4.8 & 26.8 & Leu89A & 4.7 & 26.7 \\
\hline Leu90A & 3.6 & 7.2 & Leu90A & 4.2 & 6.8 \\
\hline Glu91A & 4.0 & 29.9 & Glu91A & 3.7 & 28.9 \\
\hline Thr121A & 4.5 & 34.0 & Thr121A & 6.4 & 37.5 \\
\hline Lys127B & 4.4 & 75.1 & Lys127B & 4.9 & 75.3 \\
\hline Leu131B & 4.2 & 16.0 & Leu131B & 4.4 & 18.4 \\
\hline Arg135B & 4.8 & 27.6 & Arg135B & 4.8 & 27.6 \\
\hline
\end{tabular}

with bound water and other polar groups in the protein structure [21].

The parameters of the fluorescence spectra of tryptophan residues depend on the polarity of their microenvironment, as well as the ability of the tryptophan residue to relax during the fluorescence lifetime. It should be

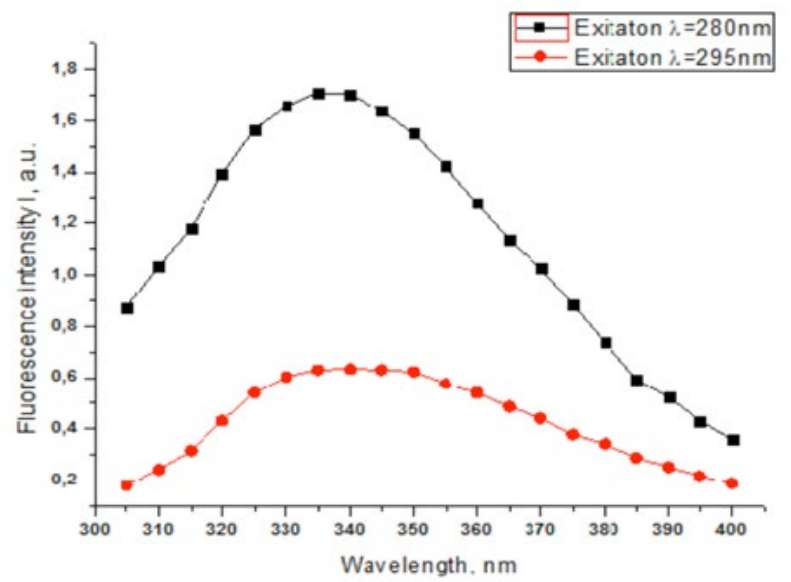

Fig. 6. Fluorescence spectra of the mutant form of catalytic module of Bos taurus tyrosyl-tRNA synthetase at excitation wavelengths of $280 \mathrm{~nm}$ and $295 \mathrm{~nm}$ keep in mind that the polarity of the tryptophan residue microenvironment is determined not only by its accessibility to the solvent molecules, but also by its own polar protein groups, which are the parts of the microenvironment [21, 22].

Previously, we have studied the intrinsic tryptophan fluorescence of native mini TyrRS and analyzed its intramolecular dynamics by fluorescence spectroscopy [27]. The analysis of the localization and microenvironments of three tryptophan residues responsible for the intrinsic fluorescence of mini TyrRS allowed us to characterize their accessibility in the structure of the enzyme dimer and the microenvironment conformational mobility. The characteristics of the tryptophan fluorescence of mutant mini TyrRS with a single tryptophan residue at position 87 indicate the immobilization of the tryptophan residue microenvironment at the dimer interface.

The mutant form of mini-TyrRS with tryptophan-87 residue, which is localized in the 
region of dimerization of the enzyme, can be effectively used to investigate the conformational changes of tyrosyl-tRNA synthetase associated with the neurodegenerative disease of Charcot-Marie-Tooth neuropathy [28, 29].

\section{Conclusions}

In this work it has been found that the replacement of Trp40 and Trp283 residues by alanine in Bos taurus mini-tyrosyl-tRNA synthetase cloned in the expression plasmid pET30a39KYRSW87 does not affect the synthesis of the mutant form of the enzyme. The amount of soluble form of recombinant mutant mini BtTyrRS expressed in E. coli strain BL21 (DE3) pLysE significantly increased when the temperature of incubation of bacterial culture was reduced from $37{ }^{\circ} \mathrm{C}$ to $25^{\circ} \mathrm{C}$. The yield of purified homogeneous mutant mini BtTyrRS upon incubation of the culture $E$. coli strain BL21 (DE3) pLysE at $25^{\circ} \mathrm{C}$ transformed with plasmid pET30a-39KYRSW87 is about $30 \mathrm{mg}$ per $1 \mathrm{~L}$ of LB culture medium. According to the fluorescence spectroscopy data and computational modeling of mini BtTyrRS the microenvironment of $\operatorname{Trp} 87$ residue in mutant form is rigid at the interface of enzyme subunits.

\section{REFERENCES}

1. Pang $Y L$, Poruri $K$, Martinis $S A$. tRNA synthetase: tRNA aminoacylation and beyond. Wiley Interdiscip Rev RNA. 2014;5(4):461-80.

2. Kornelyuk AI. Structural and functional investigation of mammalian tyrosyl-tRNA synthetase. Biopolym Cell. 1998; 14(4):349-59.

3. Korneliuk AI, Kurochkin IV, Matsuka GKh. [TyrosyltRNA synthetase from the bovine liver. Isolation and physico-chemical properties]. Mol Biol (Mosk). 1988;22(1):176-86.
4. Gnatenko DV, Korneliuk AI, Kurochkin IV, Ribkinska TA, Matsuka GKh. [Isolation and characteristics of functionally active proteolytically modified forms of tyrosyl-tRNA synthetase from bovine liver]. $U k r$ Biokhim Zh (1978). 1991;63(4):61-7.

5. Kornelyuk AI, Tas MPR, Dubrovsky AL, Murray JC. Cytokine activity of the non-catalytic EMAP-2-like domain of mammalian tyrosyl-tRNA synthetase. Biopolym Cell. 1999;15(2):168-72.

6. Levanets $O V$, Naidenov VG, Odynets KA, Woodmaska MI, Matsuka GKh, Kornelyuk AI. Homology of C-terminal non-catalytic domain of mammalian tyrosyl-tRNA synthetase with cylokine EMAP II and non-catalytic domains of methionyl- and phenylalanyl-tRNA synthetases. Biopolym Cell. 1997; 13(6):474-478.

7. Wakasugi K, Schimmel P. Highly differentiated motifs responsible for two cytokine activities of a split human tRNA synthetase. J Biol Chem. 1999; 274(33):23155-9.

8. Guo $M$, Schimmel P. Essential nontranslational functions of tRNA synthetases. Nat Chem Biol. 2013;9(3):145-53.

9. Kondratyuk Yu, Babarik M, Sidorik L, Kornelyuk O. Optimization of the process of biosynthesis of the catalytic module of mammalian tyrosyl-tRNA synthetase and its research by immunochemical methods. Bull Kyiv Taras Shevchenko Natl Univ, Biol ser. 2010; 56: 33-5.

10. Zayets VN, Tsuvarev AYu, Kolomiiets LA, Korneliuk $A I$. Site-directed mutagenesis of tryptophan residues in the structure of the catalytic module of tyrosyltRNA synthetase from Bos taurus. Cytol Genet. 2019;53(3):219-26.

11. Sahdev S, Khattar SK, Saini KS. Production of active eukaryotic proteins through bacterial expression systems: a review of the existing biotechnology strategies. Mol Cell Biochem. 2008;307(1-2):249-64.

12. Rosano GL, Ceccarelli EA. Recombinant protein expression in Escherichia coli: advances and challenges. Front Microbiol. 2014;5:172.

13. Joseph BC, Pichaimuthu S, Srimeenakshi S, Murthy M, Selvakumar K, Ganesan M, Manjunath SR. An overview of the parameters for recombinant protein expression in Escherichia coli. J Cell Sci Ther. 2015; 6(5) 
14. Inoue H, Nojima H, Okayama H. High efficiency transformation of Escherichia coli with plasmids. Gene. 1990;96(1):23-8.

15. Sambrook J, Fritsch T, Manniatis T. Molecular Cloning: A Laboratory Manual. 2th ed. New York: "Cold Spring Harbor Laboratory Press", 1989.

16. Laemmli UK. Cleavage of structural proteins during the assembly of the head of bacteriophage T4. $\mathrm{Na}$ ture. 1970;227(5259):680-5.

17. Pettersen EF, Goddard TD, Huang CC, Couch GS, Greenblatt DM, Meng EC, Ferrin TE. UCSF Chimera--a visualization system for exploratory research and analysis. J Comput Chem. 2004;25(13): 1605-12.

18. Waterhouse A, Bertoni M, Bienert S, Studer G, Tauriello G, Gumienny R, Heer FT, de Beer TAP, Rempfer C, Bordoli L, Lepore R, Schwede T. SWISSMODEL: homology modelling of protein structures and complexes. Nucleic Acids Res. 2018;46(W1): W296-W303.

19. Xu D, Zhang $Y$. Improving the physical realism and structural accuracy of protein models by a two-step atomic-level energy minimization. Biophys $J$. 2011;101(10):2525-34.

20. Chen VB, Arendall WB 3rd, Headd JJ, Keedy DA, Immormino RM, Kapral GJ, Murray LW, Richardson JS, Richardson DC. MolProbity: all-atom structure validation for macromolecular crystallography. Acta Crystallogr D Biol Crystallogr. 2010;66(Pt 1):12-21.

21. Reshetnyak YK, Burstein EA. Decomposition of protein tryptophan fluorescence spectra into lognormal components. II. The statistical proof of discreteness of tryptophan classes in proteins. Biophys J. 2001;81(3):1710-34.

22. Turoverov KK, Kuznetsova IM. Sobstvennaia fluorestsentsiia globuliarnogo aktina. Osobennosti lokalizatsii triptofanovykh ostatkov [Intrinsic fluorescence of globular actin. Features of localization of tryptophan residues]. Bioorg Khim. 1998;24(12):893-8.

23. Studier FW, Moffatt BA. Use of bacteriophage T7 RNA polymerase to direct selective high-level expression of cloned genes. J Mol Biol. 1986;189(1): 113-30.

24. Papaneophytou CP, Kontopidis G. Statistical approaches to maximize recombinant protein expres- sion in Escherichia coli: a general review. Protein Expr Purif. 2014;94:22-32.

25.Yang XL, Skene RJ, McRee DE, Schimmel P. Crystal structure of a human aminoacyl-tRNA synthetase cytokine. Proc Natl Acad Sci U S A. 2002;99(24): 15369-74.

26. Kravchuk VO, Savytskyi OV, Odynets KO, Mykuliak VV, Kornelyuk AI. Computational modeling and molecular dynamics simulations of mammalian cytoplasmic tyrosyl-tRNA synthetase and its complexes with substrates. J Biomol Struct Dyn. 2017;35(13):2772-2788.

27. Chysta SV, Kornelyuk AI. Fluorescence and dynamics of the microenvironment of tryptophan residues of eukaryotic tyrosyl-tRNA synthetase. Fizyka Zhyvogo. 2014; 21(1-2):24-8.

28. Nangle LA, Zhang $W$, Xie $W$, Yang XL, Schimmel $P$. Charcot-Marie-Tooth disease-associated mutant tRNA synthetases linked to altered dimer interface and neurite distribution defect. Proc Natl Acad Sci U S A. 2007;104(27):11239-44.

29. Odynets KA, Kornelyuk AI. Bioinformatical analysis of influence of human tyrosyl-tRNA synthetase mutations associated with neuropathy Charcot-Marie-Tooth, type $\mathrm{C}$, on its local spatial structure properties. Biopolym Cell. 2007;23(5):449-60.

\section{Виділення та характеристика мутантної форми $\mathrm{N}$-кінцевого каталітичного модуля тирозил- тРНК синтетази Bos taurus з заміною Trp 40 та Trp 283 на аланін}

В. М. Заєць, Д. М. Ложко, О. Ю. Цуварєв, Л. А. Коломієць, П. Е. Зуб, О. І. Корнелюк

Мета. Отримання мутантної однотриптофанової форми N-кінцевого каталітичного модуля тирозил-тРНК синтетази Bos taurus (міні TyrRS) для моніторингу локальних конформаційних змін методом флуоресцентної спектроскопії. Методи. Бактеріальна експресія, метал-хелатуюча хроматографія, гель-електрофорез, флуоресцентна спектроскопія, комп'ютерне моделювання. Результати. Проведено заміну двох триптофанових кодонів кодонами аланіна в кДНК, що кодує міні BtTyrRS. Ці мутації не впливають на синтез та розчинність міні $B t$ TyrRS в штамі E. coli BL21 (DE3) 
pLysE. Кількість розчинної форми мутантної міні $B t$ TyrRS в цитоплазмі бактеріальних клітин при інкубації бактеріальної культури при $25^{\circ} \mathrm{C}$ становило близько 47 \% від загальної кількості рекомбінантного білка. Комп'ютерне моделювання та флуоресцентне дослідження однотриптофанової форми міні BtTyrRS показало, що залишок $\operatorname{Trp} 87$ локалізований в області димеризації субодиниць ферменту. Характеристики флуоресценції триптофану мутантного міні BtTyrRS вказують на те, що Trp 87 локалізований в іммобілізованому мікросередовищі інтерфейсу димера. Висновки. Встановлено оптимальні умови бактеріальної експресії мутантної форми міні $B t$ TyrRS, що містить Trp 87, в культурі бактерій E. coli штаму BL21 (DE3) pLysE. Trp 87-вмісна форма міні BtTyrRS може бути використана для моніторингу локальних конформаційних змін в інтерфейсі димера фермента.

Кл юч о в і с л о в а: тирозил-тРНК синтетаза, міні TyrRS, бактеріальна експресія, флуоресцентна спектроскопія, комп'ютерне моделювання

\section{Выделение и характеристика мутантной формы N-концевого каталитического модуля тирозил-тРНК синтетазы $B$. taurus с заменой $\operatorname{Trp} 40$ и Trp 283 на аланин}

В. Н. Заец, Д. М. Ложко, А. Ю. Цуварев, Л. А. Коломиец, П. Е. Зуб, А. И. Корнелюк

Цель. Получение мутантной однотриптофановой формы N-концевого каталитического модуля тирозил-тРНК синтетазы Bos taurus (мини TyrRS) для мониторинга локальных конформационных изменений методом флуоресцентной спектроскопии. Методы. Бактериальная экспрессия, металл-хелатирующая хроматография, гель-электрофорез, флуоресцентная спектроскопия, компьютерное моделирование. Результаты. Проведена замена двух триптофановых кодонов кодонами аланина в кДНК, кодирующей мини $B t$ TyrRS. Эти мутации не влияют на синтез и растворимость мини BtTyrRS в штамме E. coli BL21 (DE3) pLysE. Количество растворимой формы мутантной мини $B t$ TyrRS в цитоплазме бактериальных клеток при инкубации бактериальной культуры при $25{ }^{\circ} \mathrm{C}$ составило около 47 \% от общего количества рекомбинантного белка. Компьютерное моделирование и флуоресцентное исследование однотриптофановой формы мини $B t$ TyrRS показало, что остаток Trp 87 локализован в области димеризации субъединиц фермента. Характеристики флуоресценции триптофана мутантной мини BtTyrRS указывают на то, что Trp 87 локализован в иммобилизованной микросреде интерфейса димера. Выводы. Установлены оптимальные условия бактериальной экспрессии мутантной формы мини $B t$ TyrRS, содержащий Trp 87, в культуре бактерий E. coli штамма BL21 (DE3) pLysE. Trp 87-содержащая форма мини BtTyrRS может быть использована для мониторинга локальных конформационных изменений в интерфейсе димера фермента.

Кл юче вы е слов а: тирозил-тРНК синтетазы, мини TyrRS, бактериальная экспрессия, флуоресцентная спектроскопия, компьютерное моделирование

Received 23.10.2019 